\title{
THE IDEA OF FREEDOM IN RADICAL AND DELIBE- RATIVE MODELS OF DEMOCRACY
}

\author{
WOJCIECH UfEL \\ wojtek.ufel@gmail.com \\ University of Wrocław, Poland
}

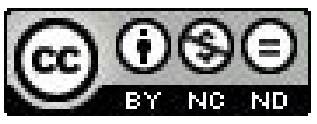

\begin{abstract}
Basing on the idea of freedom brought by I. Berlin we can derive to classical models of democracy: liberal and republican. Reflection on postmodern theories of democracy - radically plural and deliberative - points that they do not strongly differ from the traditional ones, but rather give them new challenges. Radical democracy of Ch. Mouffe and E. Laclau praising pluralism and negative freedom is a deconstruction of a liberal model, while deliberative project of J. Habermas, praising community and negative freedom, remains in a republican tradition. In the end of the article the author also presents the understanding of the educative role of society and tradition in both classical and postmodern models of democracy.
\end{abstract}

Key words: deliberative democracy, radical democracy, freedom, Habermas, Mouffe, pluralism, deliberation, postmodernism.

In the second half of the twentieth century, numerous developments had a profound influence on political theory. The rise of new social movements, collapsing of the Soviet Bloc, accelerating globalization, arising global problems, development of mass media and new forms of mass communication etc. put new challenges in front of modern societies. What is more, major changes appeared in the social sciences as well: growing influence of post-structuralism and the post modernism approach; devaluation of orthodox Marxism; evolution of critical theory; and the domination of libertarian and neo-liberal political, social and economic theories. It is in those conditions, when as a result of growing awareness of problems that contemporary political systems face, new propositions for democratic models arise. In this article I want to focus on two, perhaps most commented and influential conceptions: the radical democracy model proposed and developed by Ernesto Laclau and Chantal Mouffe; and the deliberative democracy project outlined by Jürgen Habermas.

While exploring these two, post modern approaches to democracy, I will focus on how the idea of freedom is developed in the theories. To reach my goal, I will use the notions of "positive" and "negative" freedom (liberty) introduced by Isaiah Berlin. I will also explore how the understanding of freedom in post modern concepts of democracy can be compared to the understanding of it in "modern" or "classical" approaches, namely in the liberal and republican models. I stay aware 
of the fact, that making the latter distinction is a simplification, but following J. Habermas (Habermas 1996b), I find it particularly useful in this analysis.

\section{POSITIVE AND NEGATIVE FREEDOM IN CLASSICAL MODELS OF DEMOCRACY}

I. Berlin in his essay Two Concepts of Liberty proposed what is possibly the most influential and discussed distinction among different types of freedom (or liberty, as he uses both notions interchangeably). While discussing "negative" freedom, he writes: "by being free in this sense I mean not being interfered with by others" (Berlin 1969a, p. 123). This type of liberty becomes the centre of his political theory. I. Berlin is aware, that there have to be some restrictions: "we cannot remain absolutely free, and must give up some of our liberty to preserve the rest" (Berlin 1969a, p. 126) but the restrictions cannot be taken too far and the catalogue of basic freedoms: of conscience; speech; vote etc. must be guaranteed. An individual, above all, must have a possibility to reach its own goals. "All coercion is, in so far as it frustrates human desires, bad as such" (Berlin 1969a, p. 128).

As an opposite, I. Berlin "contrasts the "positive" notion of »self-mastery" motivated by a desire of people to conceive of and act on their own goals" (Cunningham 2002, p. 36). In this case one is not treated as "free from" (the influence of others), but is "free to" (self-master herself). When considered as an attribute of an individual, both notions can be understood as two dimensions of the same thing: a person, unbounded from an influence of others, makes a decision and acts upon himself. But the difference, in fact, became significant, when eventually those two notions "historically developed in divergent directions not always by logically reputable steps, until, in the end, they came into direct conflict with each other" (Berlin 1969a, p. 132). The problem appears when the idea of "positive" freedom is being implemented into politics and, instead of an individual, appeals to the whole society.

As a liberal philosopher, I. Berlin is especially aware of authoritarian and totalitarian power, and he claims that any government ruling in the name of "positive" liberty is a first step towards those dangerous and undesirable forms of political system. This is because "positive" freedom - when the common goals are ascribed to the society - becomes an excuse for coercion. Two assumptions combined, "rational self-direction... [and] that the ends of all rational beings must of necessity fit into a single universal" (Berlin 1969a, p. 154), open the door for the rule of experts ready to force an individual to pursue a common goal, thus decreasing an amount of "negative" freedom.

On those two concepts of liberty it is possible to draw the distinction between two normative, "classic" models of democracy, liberal and republican (sometimes referred to as "civic republicanism"). "According to the liberal view, the citizen's status is determined primarily according to negative rights they have vis-à-vis the state and other citizens' (Habermas 1996b, p. 22). The liberal model of democracy is derived from the modern age philosophers such as T. Hobbes and J. Locke. Throughout the ages of development of political thought the liberal concept has 
taken many shapes and many issues have been discussed in a philosophical and political discourse. However, such features as: sovereignty; impersonal state powers; representative government; centrality of institutionalism to guarantee equality before the law and basic freedoms; separation of powers; separation of state from civil society; and competing power and interest groups has always been the core of this model (Held 2006, p. 78). With no doubt one can state, that the "negative" approach to liberty is the one more stressed than the "positive" one. However, what is also emphasized by I. Berlin, "it is sometimes necessary to constrain some freedoms, as when confronting »paradox of tolerance «... and perhaps the norms implicated in positive-libertarian conception could be appealed for guidelines" (Cunningham 2002, p. 38-39) ${ }^{42}$. But, as Frank Cunningham writes, "this is as far as one can go in the way of fitting conceptions of positive liberty into a liberal democratic theoretical framework and that they find a more comfortable home in theories of participatory democracy... or civic republicanism" (Cunningham 2002, p. 39). Thus, examination of "positive" freedom brings us closer to the republican model of democracy.

Republicanism as a model of democracy has a long tradition, from Aristotle and Athens, Cicero and Rome, through Niccolo Machiavelli and Jean Jacques Rousseau in modern times, to Hannah Arendt and Michael Sandel in contemporary political theory. However, it is beyond the scope of this paper to further examine the development of this idea ${ }^{43}$. Nevertheless, while writing about the republican model of democracy, I will refer to the main ideas of the previously mentioned thinkers, or to what is today developed in theories of communitarianism and civic republicanism. Common for this model are terms of "mixed government... the rule of law, and above all public-spirited citizenship" (Dryzek, Dunleavy 2009, p. 214). In case of this paper, it is important to stress what is named by David Held as the principles of justification in republicanism: "political participation is an essential condition of personal liberty; if citizens do not rule themselves, they will be dominated by others" (Held 2006, p. 44); and that "citizens must enjoy political and economic equality in order that nobody can be master of another and all can enjoy equal freedom and development in the process of self-determination for the common good" (Held 2006, p. 48).

The republican model of democracy assumes that citizens can create a community driven by a common conception of good. The goals of the society are agreed in a deliberative process with ethical consequences. For J. Habermas, politics in this point of view is "conceived as the reflective form of substantial political life" (Habermas 1996b, p. 21). Such a created ethical community is one, in which "political rights - preeminently rights of political participation and communication are positive liberties" (Habermas 1996b, p. 22). Thus one can admit that the republican model of democracy fulfills the two basic assumptions that I. Berlin derives from the development of the idea of "positive" freedom: rational self-direction and belief in universal goals.

42 For more information on positive-libertarian conception see Libertarianism Defended, (Machan 2006).

43 For more see (Held 2006, p. 29-55). 
William Rehg gives a good summary for this distinction between liberal and republican point of view according to the conception of "negative" and "positive" liberty: "republican views tend to ground the legitimacy of laws and policies in notions of "popular sovereignty «, whereas liberal views tend to define legitimate government in relation to the protection of individual liberty, often specified in terms of human rights" (Rehg 1996, p. xxv).

\section{FREEDOM IN POST MODERN MODELS OF DEMOCRACY}

Post modern theories of democracy appear on a critique of other, modern theories. Concerning them as insufficient, they point out their weaknesses and mistakes. However, new theories cannot totally differ from the one they criticize, thus I want to compare the post modern models with those two, already described to trace continuities and changes that occurred in political theory.

The project of "radical democracy", or "radical and plural democracy", is brought by Ch. Mouffe in her book together with E. Laclau Hegemony and Socialist Strategy, published in 1985, and then broadly commented and reformed in her numerous later writings and articles. I would like to introduce the basic concepts of this theory (Laclau, Mouffe 2001; Mouffe 1993; Mouffe 1996)

In central place in this theory is the non-essential approach to the identity, which emerged from their critique of post-Marxism. In short, E. Laclau and Ch. Mouffe summarize that "the fall of this last redoubt of class reductionism, insofar as the very unity and homogeneity of class subject has split into a set of precariously integrated positions which, once the thesis of the neutral character of the productive forces is abandoned, cannot be referred to any necessary point of future unification" (Laclau, Mouffe 2001, p. 85). This opens the way to the total deconstruction of class-based identity and, in its place, implementation of a discursively constructed identities unifying particular political subjects to the postMarxist theory. As Ch. Mouffe writes, "there is no identity that is self-present to itself and not constructed as difference" (Mouffe 1993, p. 141).

The next step in understanding E. Laclau and Ch. Mouffe's project is through the introduction of their understanding of social relations (and thus also, in a way, of what is political) in radical democracy. Those relations are based on an antagonism - that is on a hegemonic influence of the Others, which prevents one for being

fully himself. The category and its social role is clarified by Anne Marie Smith, though in very radical words: "it is only when an exploited individual begins to live her relation with capital as an antagonistic relation - that is, as a relation that is denying her identity, as something that is blocking herself from realizing what she regards as her true potential and stopping her society from becoming an ideal social order - that she is transformed into a worker who is ready to engage in subversive collective resistance" (Smith 1998, p. 67).

In her later writings $\mathrm{Ch}$. Mouffe introduced a new notion in exchange for "antagonism": "agonism", which occurs between "adversaries", "friendly enemies", that is "persons who are friends because they share a common symbolic space but also enemies because they want to organize this common symbolic space 
in a different way" (Mouffe 2000, p. 13). As antagonism now becomes the relation between enemies, its explosion can "tear up the very basis of civility" (Mouffe 2000, p. 104). The agonistic relation becomes the centre of the radical democracy project only combined with pluralistic relations among the people. However pluralism should not be understood here in its broadest definition, since "condition of possibility of pluralist democracy is at the same time the condition of impossibility of its perfect implementation" (Mouffe 2000, p. 16). It would put us in a situation, in which the pluralism would have to be understood outside the sphere of political (without antagonistic/agonistic meaning). Total pluralism perishes during the discursive construction of group identities.

From this place we can ask the question about the idea of freedom in the conception of Ch. Mouffe. As she is most of the time critical towards liberalism, she writes that pluralism itself is derived from liberal ideas: "pluralism, understood as the principle that individuals should have the possibility to organize their lives as they wish, to choose their own ends, and to realize them as they think best, is the greatest contribution of liberalism to modern society" (Mouffe 1996, p. 104). However, those conditions, truly equal to each other, can be achieved only through radically pluralistic politics, with no (discursively created) identities suppressed in the society: "the appeal to human rights enables an "agonistic " politics within the democratic polity by bringing into view the contingency of that founding distinction and hence the possibility that it might be drawn otherwise" (Schaap 2009, p. 59). In a similar way the conception of Ch. Mouffe is summarized by F. Cunningham: "The task... is to provide conditions that will reconstruct the identities of those in conflict in such a way that they are not so threatened by one another that they get locked into antagonistic relations unconstrained by adherence to liberal and democratic values" (Cunningham 2002, p. 193).

At this point I would like to cite what I. Berlin wrote about pluralism: "with the measure of »negative « liberty that it entails, [pluralism] seems to me a truer and more humane ideal than the goals of those who seek in the great, disciplined, authoritarian structures the ideal of "positive« self-mastery" (Berlin 1969a, p. 171). Hence, considering $\mathrm{Ch}$. Mouffe's priority given to pluralism and commitment to the possibility of organising one's goal as he wishes, the ideal of freedom she is referring to is certainly a "negative" liberty.

The next model I am going to examine in this paper is a deliberative model of democracy. The project of deliberative democracy is developed by many contemporary political thinkers and philosophers, but the biggest contribution to this theory is certainly the one of J. Habermas, with his work unfolding since 1962 writing The Structural Transformation of the Public Sphere, presented finally in Between Facts and Norms first published in 1996. In the latter he summarizes his previous achievements in the theory of discourse, public communication, law and deliberative procedures, giving final shape to his political theory.

As the major focus of deliberative politics, J. Habermas conceives the democratic legitimacy of law in modern, pluralistic societies. The law lies between facts (facticity) and norms (validity), between the empirical realm and moral expectations. It is a "system of coercible rules and impersonal procedures that also 
involves an appeal to reason, that all citizens should, at least ideally, find acceptable" (Rehg 1996, p. xi). As contemporary pluralistic and multi-cultural societies are not capable of developing one morally bounding ideology or substantial ethical doctrine, J. Habermas introduces a deliberative procedure that is supposed to grant a radically democratic legitimacy of law.

Deliberation itself in J. Habermas refers to the process in which rational, moral and equal citizens, through multiple acts of communication exchange arguments in order to achieve mutual understanding of their differing points of views: "for the centrepiece of deliberative politics consists in a network of discourses and bargaining processes that is supposed to facilitate the rational solution of pragmatic, moral, and ethical questions" (Habermas 1996a, p. 320). Those three mentioned conditions - of rationality, morality and equality - are the conditions of every human being, so the ideal situation of deliberation is, in that case, not exclusive. Everybody has got the same chance to speak up and propose an agenda, and the outcome of the procedure depends only on the unbiased judgement of arguments. In the deliberative ideal, the final outcome would be a shared understanding of every participant situation and point of view and consensual agreement on a rational and morally acceptable outcome. Furthermore, the issue is never closed to re-discussion, if the conditions change.

There are two another conditions of deliberative procedure in the public sphere: "the participants of the argumentation should leave their own particularities aside when they enter into the deliberation of common issues" (Üstüner 2006, p. 39); and they should all apply the rules of communication. Those "most important principles of communicative action are presupposed in linguistic communication" (Cunningham 2002, p. 176), and thus J. Habermas can establish a "discourse theory of ethics where participants are both willing and able to strive for agreement in accordance with the rules implicit in language, and moral judgements are assessed according to whether they could be accepted by participants in such discourse" (Cunningham 2002, p. 176).

The result of the deliberation is not solely the legitimacy of law. As J. Habermas writes, "every association that institutionalizes such a procedure thereby constitutes itself as a body of citizens" (Habermas 1996a, p. 306). Through a positive law a community is achieved, but it should be emphasized that this community is not moral, but rather "takes the shape of a self-organizing legal community" (Habermas 1996a, p. 326).

It is not an easy task to present J. Habermas' understanding of freedom, as his theory is very complex. Fahriye Üstüner writes that "he tries to convert the selfinterested individual into a self-governing citizen as in the republican view, but unlike that, he assumes this is possible without necessarily sharing substantial values, but through communication and deliberation in the political public sphere" (Üstüner 2006, p. 42). This would suggest a complex conception of freedom as a mix between "negative" and "positive", with the latter one constituted by the first. However, the understanding of J. Habermas should be grasped in a slightly different way. As he writes, "individual private rights cannot even be adequately formulated, let alone politically implemented, if those affected have not first engaged 
in public discussions" (Habermas 1996a, p. 450). So in his conception, "the private autonomy that was at first abstractly posited can retroactively assume an elaborated legal shape" (Habermas 1996a, p. 121). Thus, a logical order of freedom in a public sphere gives priority to the "positive" liberty, and only afterwords - through the democratic procedures - the "negative" liberty can attain legitimacy. Nevertheless, "the principle of law giving popular sovereignty appears to follow upon the subjective liberties of private autonomy" (Maus 2002, p. 91).

The issue as to whether the J. Habermas' conception is stressing more the "negative" or "positive" freedom, whether the subjective liberties are given as in a liberal vision or disposed by popular sovereignty is broadly discussed ${ }^{44}$. To give a solution to this problem, I would like to propose a three-step understanding of freedom in this conception: at the first step, individuals are free in a "negative" way, but this freedom appeals only to the private sphere; in the second step, free and equal individuals are treated as citizens, who enter a deliberation procedure in a public sphere, which is the step of "positive" freedom; in the end, "negative" freedom gains legitimacy in public sphere as an effect of communicative and procedural action.

\section{CONCLUSIONS}

To summarize, I would like to focus on similarities and differences between "modern" and "post modern" models of democracy. At the end I will try to answer the question, if there is a need to introduce new models of democracy, or if the post modern theories can be assigned to liberal and republican models.

The theory of Ch. Mouffe puts the main stress on "negative" freedom. Her concept can be in many issues adjusted to the liberal model of democracy, especially concerning her focus on competing powers and interest groups, pluralism, and the value assigned to the possibility of achieving one's goals and desires. However, she gives a strong critique to liberalism as well, but the critique does not oppose her to this model, rather what is the matter is that "against the classical radical tradition, contemporary radical democrats deconstruct rather than reject the liberal tradition" (Norval 2001, p. 588). Nevertheless, it is crucial to recognize the new challenges given to democracy in its liberal and pluralistic meaning by the work of Ch. Mouffe, especially concerning identity politics, ecology and struggle for equal rights.

The task of assigning J. Habermas' concept to one of the classical models is, however, much more complicated. The appearance and, in fact, centrality of the idea of "positive" freedom in his theory undoubtedly puts it closer towards the republican model of democracy, but there are some significant differences pointed by the German philosopher himself: the procedural point of view breaks with the tradition of substantially ethical community; gives the central position to constitutionalism and law rather than to morality; and gives priority to the society-centred understanding of the politics rather than to the self-centred one (Habermas 1996b, p. 24-27).

But those differences do not oppose the republican model in a way that would lead to its rejection. Again, it is rather a challenge given to the classic model of

$44 \quad$ The main voices in the discussion are presented in the article Popular Sovereignty and Liberal Rights (Maus 2002). 
democracy in order to adjust it to contemporary, pluralistic societies and to radically democratic demands of all.

Another conclusion I want to draw on the understanding of freedom in those models directly corresponds with the scope of this journal's issue - the educational role of culture (including political institutions), history and society. The role is especially evident while considering the process of political socialization. In the next few paragraphs I will show, that this role becomes another element binding the republican and deliberative model on the one hand, and the liberal model with radical on the other.

Republicanism since ancient times has emphasized the role of tradition, society and state in "creating" or "educating" a "good citizen". Since J. J. Rousseau, this concept exceeded the strict sphere of political, and became more substantive, and influenced morality more than ever before (Dziubka 2010). If we consider the thought of J. Habermas, we can notice many analogies to that model - it is the state and society, via constitutional procedures and informal will - and opinion-formation, which are the eventual creators of an individual. And, what's more, this individual can become fully a subject of politics only when considered in relation to this whole system. Only than he becomes what has earlier been named as a "good citizen".

The same problem is treated in a different way from the liberal point of view. Of course, the role of socialization is not denied as unimportant. But the education of the citizens is rather treated as their right than a duty. Moreover, growing influence of the state in the field of "creating new citizens" is strictly considered as a threat to freedom. It does not imply the rejection of the educational role of society and culture, e. g. for Friedrich Hayek freedom to learn from the others was the main element of every system, that wanted to develop ${ }^{45}$. But as long as it is incogitant and/or imposed on humans, liberalism was very critical about every manifestation of it. John Stuart Mill even called it a "despotism" and wrote, that "the despotism of custom is everywhere the standing hindrance to human advancement" (Mill 2001, p. 65).

Finally, in Ch. Mouffe's concept we can see again the critique of the educational role of society and culture. This is expressed in a negative approach to hegemony. An individual is rather an object of politics under the rule of hegemonic, imposed discourses and cannot fully become a political subject as long as she is not free from any constraints. Thus, subverting those constraints is strongly linked to rejection or at least reconsideration and deconstruction of the educational systems in every society.

\section{BIBLIOGRAPHY}

Benhabib S. (ed.) (1996), Democracy and Difference, Princeton University Press, Princeton.

Berlin I. (1969a), Two Concepts of Liberty, [in:] Berlin I., Four Essays on Liberty, Oxford University Press, London, Oxford, New York.

Berlin I. (1969b), Four Essays on Liberty, Oxford University Press, London, Oxford, New York.

Clarke P.B., Foweraker J. (eds.) (2001), Encyclopedia of Democratic Thought, Routledge, London, New York.

45 In his profound book The Constitution of Liberty he argues that spontaneous, natural order (cosmos) is always more effective in bringing to human development than artificial and teleological order imposed on society (taxis) (Hayek 1960). 
Cunningham F. (2002), Theories of Democracy. A Critical Introduction, Routledge, New York.

Dryzek J. S., Dunleavy P. (2009), Theories of the Democratic State, Palgrave Mcmillan, Hampshire, New York.

Dziubka K. (2008), Obywatelskość jako virtu podmiotu demokracji, Wydawnictwo Uniwersytetu Wrocławskiego, Wrocław.

Habermas J. (1996a), Between Facts and Norms, MIT Press, Cambridge, Massachusetts.

Habermas J. (1996b), Three Normative Models of Democracy, [in:] Benhabib S. (ed.), Democracy and Difference, Princeton University Press, Princeton.

Hayek F. (1960), The Constitution of Liberty, University of Chicago Press, Chicago.

Held D. (2006), Models of Democracy, MPG Books Ltd, Cambridge.

Laclau E., Mouffe C. (2001), Hegemony and Socialist Strategy. Towards a Radical Democratic Politics, Verso, London, New York.

Little A., Lloyd M. (eds.) (2009), The Politics of Radical Democracy, Edinburgh University Press, Edinburgh.

Machan T. R. (2006), Libertarianism Defended, Ashgate, Hampshire.

Maus I. (2002), Popular Sovereignty and Liberal Rights, [in:] von Schomberg B., Bayes K. (eds.), Discourse and Democracy. Essays on Habermas's Between Facts and Norms, SUNY Press, New York.

Mill J. S. (2001), On liberty, Batoche Books, Kitchener.

Mouffe C. (1993), The Return of the Political, Verso, London, New York.

Mouffe C. (1996), Radical Democracy or Liberal Democracy?, [in:] Trend D. (ed.), Radical Democracy. Identity, Citizenship, And the State, Routledge, New York.

Mouffe C. (2000), The Democratic Paradox, Verso, London.

Norval A. (2001), Pluralism, [in:] Clarke P.B., Foweraker J. (eds.), Encyclopedia of Democratic Thought, Routledge, London, New York.

Rehg W. (1996), Translator's Introduction, [in:] Habermas J., Between Facts and Norms, MIT Press, Cambridge, Massachusetts.

Schaap A. (2009), Aboriginal Sovereignty and the Democratic Paradox, [in:] Little A., Lloyd M. (eds.), The Politics of Radical Democracy, Edinburgh University Press, Edinburgh.

von Schomberg B., Bayes K. (eds.) (2002), Discourse and Democracy. Essays on Habermas's Between Facts and Norms, SUNY Press, New York.

Smith A. M. (1998), Laclau and Mouffe: The Radical Democratic Imaginary, Routledge, London, New York.

Trend D. (ed.) (1996), Radical Democracy. Identity, Citizenship, And the State, Routledge, New York.

Üstüner F. (2006), The Political Public Sphere as the Maintenance of Order: Convergence in Hannah Arendt and Jürgen Habermas, "Boğaziçi Journal” 20 (1-2). 